\title{
Biometrics and grain yield of sorghum varieties irrigated with salt water
}

\author{
Miguel J. M. Guimarães ${ }^{1}$, Welson L. Simões ${ }^{2}$, Anderson R. de Oliveira ${ }^{2}$, Gherman G. L. de Araujo², \\ Ênio F. de F. e Silva ${ }^{3} \&$ Lilia G. Willadino ${ }^{3}$
}

\footnotetext{
${ }^{1}$ Universidade Federal do Vale do São Francisco/Programa de Pós-Graduação em Engenharia Agrícola. Juazeiro, BA, Brasil. E-mail: mjmguimaraes@hotmail.com (Corresponding author) - ORCID: 0000-0002-5497-6442

${ }^{2}$ Embrapa Semiárido. Petrolina, PE, Brasil. E-mail: welson.simoes@embrapa.br - ORCID: 0000-0003-1474-9410; anderson.oliveira@embrapa.br - ORCID: 00000003-4089-0995; gherman.araujo@embrapa.br - ORCID: 0000-0001-9605-1096

${ }^{3}$ Universidade Federal Rural de Pernambuco/Departamento de Engenharia Agrícola/Programa de Pós-Graduação em Engenharia Agrícola. Recife, PE, Brasil. E-mail: enio.fsilva@ufrpe.br - ORCID: 0000-0002-8652-503X; willadino.lilia@gmail.com - ORCID: 0000-0003-0491-4443
}

\begin{abstract}
The objective of this study was to identify sorghum varieties that have growth and grain yield potential under saline conditions. The study was conducted in 2016 at a greenhouse of the Embrapa Semiárido, in Petrolina, state of Pernambuco, Brazil (9 8' 8.9” S, $40^{\circ} 18^{\prime} 33.6^{\prime \prime} \mathrm{W}$, and altitude of $373 \mathrm{~m}$ ). A randomized block experimental design, with a $6 \times 5$ factorial arrangement, and three replications was used. The treatments consisted of six grain sorghum varieties (1011-IPA, 2502-IPA, 2564-IPA, 2600-IPA, Ponta Negra, and Qualimax), and five salinity levels of the irrigation water $\left(\mathrm{EC}_{\mathrm{w}}=0,1.5,3.0,6.0\right.$, and $\left.12.0 \mathrm{dS} \mathrm{m} \mathrm{m}^{-1}\right)$. Plant height, stem diameter, dry matter yield, width and length of the +3 leaf, total leaf area, water use efficiency, and grain yield were evaluated. The sorghum varieties 2502-IPA and 1011-IPA presented the highest grain yields when using an $\mathrm{EC}_{\mathrm{w}}$ of $6.0 \mathrm{dS} \mathrm{m}^{-1}$, followed by Ponta Negra, Qualimax, and 2600-IPA. The 2564-IPA, 2600-IPA, and Qualimax varieties were more sensitive to the salinity effects, with reductions of $50 \%$ of the production with $\mathrm{EC}_{\mathrm{w}}$ of $3.52,2.75$, and $4.38 \mathrm{dS} \mathrm{m} \mathrm{m}^{-1}$, respectively.
\end{abstract}

Key words: salinity, Sorghum bicolor L., semi-arid

\section{Biometria e produção de variedades de sorgo granífero irrigado com águas salinas}

RESUMO: Objetivou-se com o presente estudo identificar variedades de sorgo granífero com maior potencial de crescimento e produção de grãos sob condições salinas. O estudo foi conduzido em casa de vegetação localizada na sede da Embrapa Semiárido, Petrolina, PE (9 8’ 8,9” S 40 18’ 33,6” O, 373 m de altitude), no ano de 2016. Adotou-se o delineamento experimental em blocos casualizados, com esquema fatorial $6 \times 5$, com seis variedades de sorgo granífero (1011-IPA, 2502-IPA, 2564-IPA, 2600-IPA, Ponta Negra e Qualimax) irrigadas com água salina com cinco níveis de salinidade $\left(\mathrm{CEa}=0 ; 1,5 ; 3,0 ; 6,0\right.$ e 12,0 dS m $\left.\mathrm{m}^{-1}\right)$, em três repetições. Foram avaliadas as variáveis altura da planta, diâmetro do colmo, produção de massa seca, largura e comprimento da folha +3 , área foliar total, eficiência do uso da água e produção de grãos. As variedades de sorgo 2502-IPA e 1011-IPA apresentaram as maiores produções de grãos quando usando uma CEa de $6.0 \mathrm{dS} \mathrm{m}^{-1}$, seguida por Ponta Negra, Qualimax e 2600-IPA. As variedades 2564-IPA, 2600-IPA e Qualimax foram mais sensitivas aos efeitos da salinidade, com reduções de $50 \%$ na produção com CEa de $3,52,2,75$ e $4,38 \mathrm{dS} \mathrm{m}^{-1}$, respectivamente.

Palavras-chave: salinidade, Sorghum bicolor L., semiárido 


\section{INTRODUCTION}

Water is one of the most important components for the life of plants; its availability and quality affects directly metabolic processes of plants. These effects are more pronounced in arid and semi-arid regions, which have low water availability, and the water is often saline. Considering that severe abiotic stress causes great damage to plants, the use of techniques that minimize stress caused by the salinity of the irrigation water is important. Thus, the use of adapted plants to saline environments is essential for the viability of crops.

Sorghum bicolor (L.) Moench presents salt-tolerant accessions (Shakeri et al., 2017), thus, it is an alternative for production systems that use irrigation with salt water. The genetic variability of this crop has allowed the development of several breeding programs. These materials present diverse agronomic characteristics, which are affected by several environmental factors, such as climatic conditions (Albuquerque et al., 2013), soil fertility (Santos et al., 2014), and water availability (Tardin et al., 2013), and salinity (Guimarães et al., 2016).

The tolerance of plants to salinity is associated with the development of mechanisms that contribute to minimize salt stress. Theses mechanisms have different energy costs for the plants, which affect negatively their growth and, consequently, the grain yield of the crop (Igartua et al., 1995; Hassanein et al., 2010). In this context, the objective of this study was to identify sorghum varieties that have growth and grain yield potential under saline conditions

\section{Material ANd Methods}

The study was conducted in a greenhouse at the Brazilian Agricultural Research Corporation (Embrapa Semiárido), in Petrolina, state of Pernambuco, Brazil ( $9^{\circ}$ 8' 8.9" S $40^{\circ} 18^{\prime}$ $\left.33.6^{\prime \prime} \mathrm{W}\right)$. The region presents a tropical semi-arid climate, with average annual precipitation of $400 \mathrm{~mm}$, average relative air humidity of $67.8 \%$, and average air temperature of $26.5^{\circ} \mathrm{C}$ (Reddy \& Amorim Neto, 1983).

A randomized block experimental design, with a $6 \times 5$ factorial arrangement and three replications was used. The treatments consisted of six grain sorghum varieties (1011-IPA, 2502-IPA, 2564-IPA, 2600-IPA, Ponta Negra, and Qualimax), and five salinity levels of the irrigation water $\left(\mathrm{EC}_{\mathrm{w}}=0,1.5,3.0\right.$, 6.0, and $12.0 \mathrm{dS} \mathrm{m}^{-1}$ ).

Sorghum seeds were planted in $20 \mathrm{dm}^{3}$ plastic pots filled with a $3 \mathrm{~cm}$ layer of gravel at the bottom, and $15 \mathrm{~kg}$ of soil collected from the $0-20 \mathrm{~cm}$ layer of a sandy loam textured soil classified by the Embrapa as latosolic Dystrophic Yellow Argissolo, which presented the following characteristics: electrical conductivity of $0.23 \mathrm{dS} \mathrm{m}^{-1}, \mathrm{pH}$ of $5.7 ; 0.7 \mathrm{cmol}_{\mathrm{c}} \mathrm{dm}^{-3}$ of $\mathrm{Mg} ; 1.0 \mathrm{cmol}_{\mathrm{c}} \mathrm{dm}^{-3}$ of $\mathrm{Ca} ; 1.6 \mathrm{cmol}_{\mathrm{c}} \mathrm{dm}^{-3}$ of $\mathrm{H}+\mathrm{Al}$, $0.33 \mathrm{cmol}_{\mathrm{c}} \mathrm{dm}^{-3}$ of $\mathrm{K}, 0.07 \mathrm{cmol} \mathrm{dm}_{c}^{-3}$ of $\mathrm{Na}, 84.7 \%$ of sand, $13.5 \%$ of silt, and $1.8 \%$ of clay. Five seeds were planted per pot, with $2 \mathrm{~cm}$ depth. The plants were thinned, leaving only one plant per pot when the plants reached an average height of $15 \mathrm{~cm}$ (approximately 12 days after sowing) and, then, the irrigations with the respective salt concentrations started.
Soil fertilization consisted of $\left(\mathrm{mg} \mathrm{dm}^{-3}\right)$ : N (160), P (400), K (210), Ca (150), Mg (50), S (180), B (0.81), Cu (1.33), Mo (0.15), Mn (3.66), $\mathrm{Zn}(4.0)$, and Fe (0.1); using the sources $\left(\mathrm{NH}_{4}\right)_{2} \mathrm{SO}_{4}, \mathrm{KH}_{2} \mathrm{SO}_{4}, \mathrm{NaH}_{2} \mathrm{PO}_{4} . \mathrm{H}_{2} \mathrm{O}, \mathrm{Ca}\left(\mathrm{NO}_{3}\right)_{2}, \mathrm{MgSO}_{4}$, $\mathrm{CaCl}_{2} .2 \mathrm{H}_{2} \mathrm{O}, \mathrm{H}_{3} \mathrm{BO}_{3}, \mathrm{CuSO}_{4} .5 \mathrm{H}_{2} \mathrm{O},\left(\mathrm{NH}_{4}\right)_{6} \mathrm{Mo}_{7} \mathrm{O}_{24} .4 \mathrm{H}_{2} \mathrm{O}$, $\mathrm{MnSO}_{4} \cdot \mathrm{H}_{2} \mathrm{O}, \mathrm{ZnSO}_{4} \cdot \mathrm{H}_{2} \mathrm{O}, \mathrm{FeSO}_{4} \cdot 7 \mathrm{H}_{2} \mathrm{O}$, and NaEDTA. Soil fertilization started after thinning and was divided into three equal portions with 25-day intervals.

Irrigation water was salinized using the $\mathrm{NaCl}, \mathrm{CaCl}_{2} \cdot 2 \mathrm{H}_{2} \mathrm{O}$, and $\mathrm{MgSO}_{4} \cdot 7 \mathrm{H}_{2} \mathrm{O}$ salts to obtain a 7:2:1 equivalent ratio for $\mathrm{Na}: \mathrm{Ca}: \mathrm{Mg}$ (Aquino et al., 2007).

Weighing lysimeters were installed in all pots of a block for the irrigation management. The lysimeters were equipped with load cells (TSD model, AEPH, $50 \mathrm{~kg}$ capacity) installed under a metal base with a device for collecting excess drained water. The load cells were connected to two multiplexers (AM16/32B) coupled to a datalogger (CR1000), which performed readings every $15 \mathrm{~s}$. The lysimeters were calibrated based on known weights, simulating amounts of water retained in the soil between the permanent wilting point and maximum water retention capacity of the soil.

Irrigations were carried out every two days, using a water depth corresponding to water consumption of the plant, plus a $15 \%$ leaching fraction to maintain a balanced salt concentration in the soil.

Harvesting was performed when the central grains of the panicle had a dry appearance. The plants were cut at a height of $10 \mathrm{~cm}$ from the ground and the following biometric parameters were evaluated: plant height, stem diameter, number of leaves, and length and width of the +3 leaf. The plants were separated in stems, leaves, panicles, grains, and roots to determine their fresh weights; then, they were taken to a forced-air circulation oven at $60{ }^{\circ} \mathrm{C}$ until constant weight to determine their dry weight. The fresh weight of the grains was used to calculate the grain yield per plant.

Leaf area (LA) was estimated using the widths and lengths of the +3 leaf, and number of leaves (NL), according to the model proposed by Mondo et al. (2009) for plants with linear leaf blades. Water use efficiency (WUE) was calculated by the ratio between total dry weight (shoot + root) and plant water consumption.

The data were subjected to analysis of variance (ANOVA) using the Sisvar 5.0 program. The effects of the salinity levels were compared through polynomial regression models of first and second degrees when significant at 0.01 or 0.05 probability level. The Scott Knott test at 0.05 probability level was used for grouping the varieties.

\section{Results AND Discussion}

No significant interaction between sorghum varieties and water salinity (electrical conductivity - $\mathrm{EC}_{\mathrm{w}}$ ) was found for the variables plant height $(\mathrm{PH})$, stem diameter $(\mathrm{SD})$, length and width of the +3 leaf $(L W+3)$, total leaf area (TLA), and root dry weight (RDW). However, significant interactions were found for shoot dry weight (SDW), water use efficiency (WUE), and grain yield.

The growth variables presented different results (Table 1). Plants of the Qualimax variety had higher heights, regardless 
Table 1. Plant height $(\mathrm{PH})$, stem diameter $(\mathrm{SD})$, length and width of the +3 leaf $(\mathrm{LW}+3)$, total leaf area (TLA), and root dry weight (RDW) of sorghum plants irrigated with salt water

\begin{tabular}{|c|c|c|c|c|c|c|}
\hline \multirow{2}{*}{ Variety } & \multirow{2}{*}{$\begin{array}{c}\mathrm{PH} \\
\text { (cm) }\end{array}$} & \multirow{2}{*}{$\begin{array}{c}\text { SD } \\
(\mathrm{mm})\end{array}$} & \multicolumn{2}{|c|}{$\mathrm{LW}+3(\mathrm{~cm})$} & \multirow{2}{*}{$\begin{array}{c}\text { TLA } \\
\left(\mathrm{cm}^{2}\right)\end{array}$} & \multirow{2}{*}{$\begin{array}{c}\text { RDW } \\
\text { (g) }\end{array}$} \\
\hline & & & Width & Length & & \\
\hline 1011-IPA & $98.33 \mathrm{c}$ & $12.65 b$ & $6.38 \mathrm{~b}$ & $74.07 \mathrm{~b}$ & $2531.34 \mathrm{~b}$ & $47.79 \mathrm{a}$ \\
\hline 2502-IPA & $109.40 \mathrm{C}$ & $15.69 \mathrm{a}$ & $7.31 \mathrm{a}$ & $75.80 \mathrm{~b}$ & $3568.56 \mathrm{a}$ & $32.13 b$ \\
\hline 2564-IPA & $108.90 \mathrm{C}$ & $15.38 \mathrm{a}$ & $7.73 \mathrm{a}$ & $72.93 \mathrm{~b}$ & $3855.85 \mathrm{a}$ & $40.73 \mathrm{a}$ \\
\hline 2600-IPA & $107.27 \mathrm{C}$ & $10.85 \mathrm{C}$ & $6.50 \mathrm{~b}$ & $68.67 \mathrm{~b}$ & $2315.23 b$ & $24.72 b$ \\
\hline Ponta Negra & $126.33 b$ & $16.32 \mathrm{a}$ & $6.92 \mathrm{~b}$ & $83.00 \mathrm{a}$ & $3824.90 \mathrm{a}$ & $54.26 \mathrm{a}$ \\
\hline Qualimax & $136.63 \mathrm{a}$ & $14.83 \mathrm{a}$ & $6.89 \mathrm{~b}$ & $71.87 \mathrm{~b}$ & $2751.54 \mathrm{~b}$ & $39.34 \mathrm{a}$ \\
\hline
\end{tabular}

Means followed by the same letter in the columns do not differ by the Scott Knott test at 0.05 probability level

of the salinity level of the irrigation water, followed by Ponta Negra and the other varieties, which presented no statistical differences among them. The 2502-IPA, 2564-IPA, Ponta Negra, and Qualimax varieties presented the largest stem diameters, with averages between 14.83 and $16.32 \mathrm{~mm}$.

Plant size is an important characteristic for the selection of sorghum cultivars. Cultivars that present lower plant height are associated with higher stem resistance, presenting less susceptibility to lodging and breaking (Silva et al., 2009). Thus, the varieties 2502-IPA and 2564-IPA present greater grain yield potential due to their lower heights and larger stem diameters; and the varieties 1011-IPA and Ponta Negra have intermediate potentials; 1011-IPA due to its smaller height, and intermediate stem diameter, and Ponta Negra due to its intermediate height, and greater stem diameter.

The factors evaluated had no significant effect on the number of leaves of the plants, which presented a mean of nine leaves $(\mathrm{CV}=17.19 \%)$. The varieties 2502-IPA and 2564-IPA had significantly longer leaves, and Ponta Negra had broader leaves. This resulted in a higher total leaf area (TLA) for these varieties (Table 1), since TLA is calculated according to leaf biometric characteristics (length and width). This characteristic is desirable, since the photosynthetic process depends on the interception of light energy and its conversion into chemical energy, which is a process that occurs directly in the leaf (Taiz \& Zeiger, 2013).

The Ponta Negra, 1011-IPA, Qualimax, and 2564-IPA had higher root dry weights than the other varieties (Table 1). The differences between the growth variables of these varieties, regardless of the salinity levels studied, showed morphological characteristics that may favor their adaptability to saline stress conditions, since in many cases, is the root sensitivity to stress that limits the productivity (Steppuhn \& Raney, 2005).

The increase in salinity level in the irrigation water affected significantly almost all variables analyzed (Figure 1). Plant height decreased about $9 \mathrm{~cm}$ (5.82\%) (Figure 1A), stem diameter decreased approximately $0.5 \mathrm{~mm}(2.87 \%)$ (Figure 1B), width of the +3 leaf decreased $0.26 \mathrm{~cm}(3.27 \%)$ (Figure 1D), and root dry weight decreased $4.48 \mathrm{~g}(7.47 \%)$ (Figure $1 \mathrm{~F}$ ) per unit increase in salinity level $\left(\mathrm{EC}_{\mathrm{w}}\right)$.

Several studies also found significant reductions in biometric parameters of plants with increasing salinity levels. Tabatabaei \& Anagholi (2012) evaluated the initial growth of sorghum varieties under saline conditions and found reductions of more than $50 \%$ in plants grown under salinity levels higher than $10 \mathrm{dS} \mathrm{m}^{-1}$. Guimarães et al. (2016) evaluated
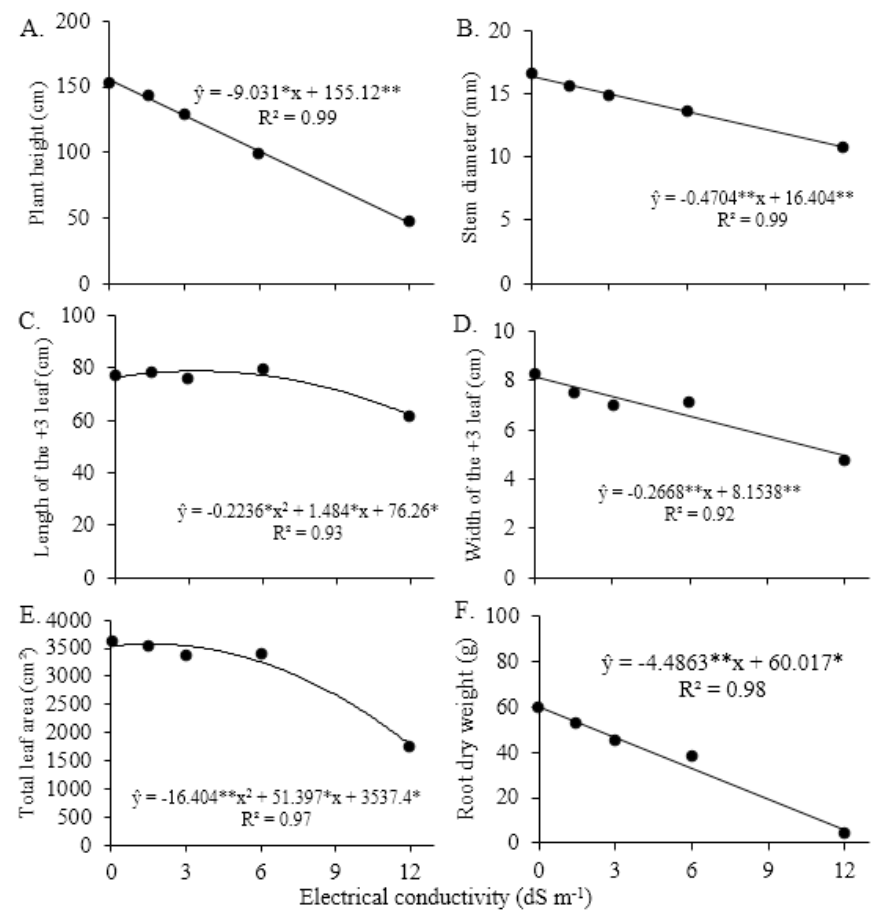

${ }^{* *}$ and ${ }^{*}$ Significant regression coefficient at 0.01 and 0.05 probability, respectively

Figure 1. Plant height (A), stem diameter (B), length (C) and width (D) of the +3 leaf, total leaf area $(\mathrm{E})$, and root dry weight (F) of sorghum varieties subjected to different salinity levels of the irrigation water

forage sorghum varieties under irrigation with saline effluent and found significant reductions in plant height and in stem diameter with increasing soil salinity.

The length of the +3 leaf, and total leaf area fitted to the quadratic model, with reductions when water salinity exceeded 3.32 , and $1.56 \mathrm{dS} \mathrm{m}^{-1}$, respectively. These reductions were more pronounced when the $\mathrm{EC}_{\mathrm{w}}$ reached levels above $6.0 \mathrm{dS} \mathrm{m} \mathrm{m}^{-1}$ (Figures $1 \mathrm{C}$ and E). Reductions in leaf area is an important adaptive mechanism of plants grown under excessive salt or water stress; they reduce transpiration and, consequently, decrease $\mathrm{Na}^{+}$, and $\mathrm{Cl}^{-}$ions in the xylem, promoting water conservation in plant tissues (Taiz \& Zeiger, 2013).

The sorghum varieties had different shoot dry weight (SDW). The 2502-IPA, 2564-IPA, 2600-IPA, Ponta Negra, and Qualimax varieties presented linear reductions with increasing salinity level, whereas the 1011-IPA variety fitted to a quadratic model. The 2564-IPA, 2600-IPA, and Ponta Negra presented reductions in SDW of $50 \%$ at low salinity levels $6.25,6.50$, and $6.89 \mathrm{dS} \mathrm{m}^{-1}$, respectively compared to the 1011-IPA, 2502-IPA, and Qualimax which presented reductions in SDW of 50\% at higher levels 8.67, 6.84, and 7.21 dS $\mathrm{m}^{-1}$, respectively (Figure 2). 


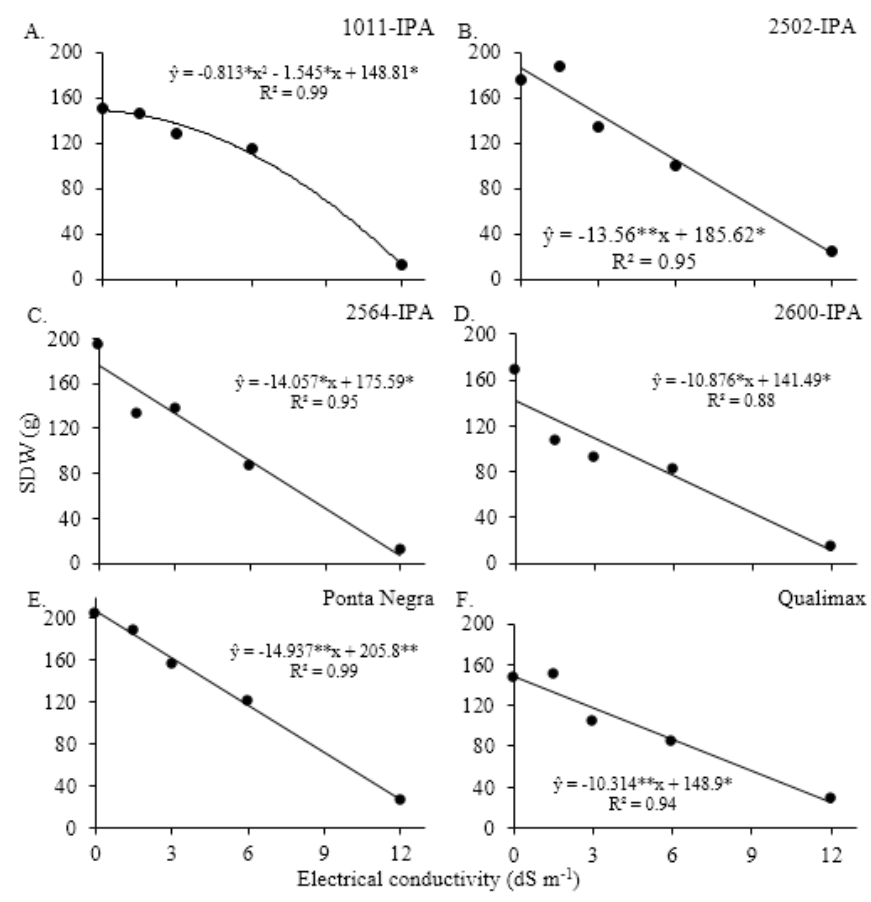

${ }^{* *}$ and ${ }^{*}$ Significant regression coefficient at 0.01 and 0.05 probability, respectively

Figure 2. Shoot dry weight (SDW) of sorghum varieties subjected to different salinity levels of the irrigation water

The reductions in plant growth caused by saline stress (Figures 1 and 2) may be associated with the toxic effect of excess salts in the root environment, leading to nutritional imbalance, and affecting important physiological processes of plant growth, and development (Willadino \& Camara, 2010). Moreover, water uptake by roots reduce due to the decreased water potential in these soils (Tigabu et al., 2013).

Reductions in the growth of sorghum plants are found in several studies in different saline conditions. Sun et al. (2014) found reductions of up to $52 \%$ in the production of sorghum varieties when irrigated with salt water of up to $10 \mathrm{dS} \mathrm{m}^{-1}$. Niu et al. (2012), evaluating sorghum genotypes (SS304, NK7829, Sordan79, and KS585) irrigated with salt water with $8 \mathrm{dS} \mathrm{m}^{-1}$, found that salinity affects specifically each genotype, with reductions of up to $79 \%$ in the SDW of the genotype KS585. Shakeri \& Emam (2017) evaluated biomass production of 36 sorghum cultivars irrigated with salt water and found reductions of up to $66 \%$ when using irrigation water with $\mathrm{EC}_{\mathrm{w}}$ of up to $12 \mathrm{dS} \mathrm{m}^{-1}$.

All these studies concluded that the genotypes or cultivars of Sorghum bicolor L. have specific responses to salinity levels, regarding the effects on plant growth and production.

Considering that water use efficiency (WUE) is the ratio between accumulated dry biomass (grams) and water consumption (liters), a significant reduction was observed with increasing salinity levels for all cultivars. WUE reduction of $50 \%$ was found with the $\mathrm{EC}_{\mathrm{w}}$ of 9.85 (1011-IPA), 9.00 (2502IPA), 6.92 (2564-IPA), 7.50 (2600-IPA), 10.25 (Ponta Negra), and 8.86 (Qualimax) $\mathrm{dS} \mathrm{m}^{-1}$ (Figure 3). These reductions indicate problems in water use by the plants for producing biomass with increasing salinity, and different effects for the production and water consumption of the plants, since the plants consumed more and produced less (Santos Júnior et al., 2013).

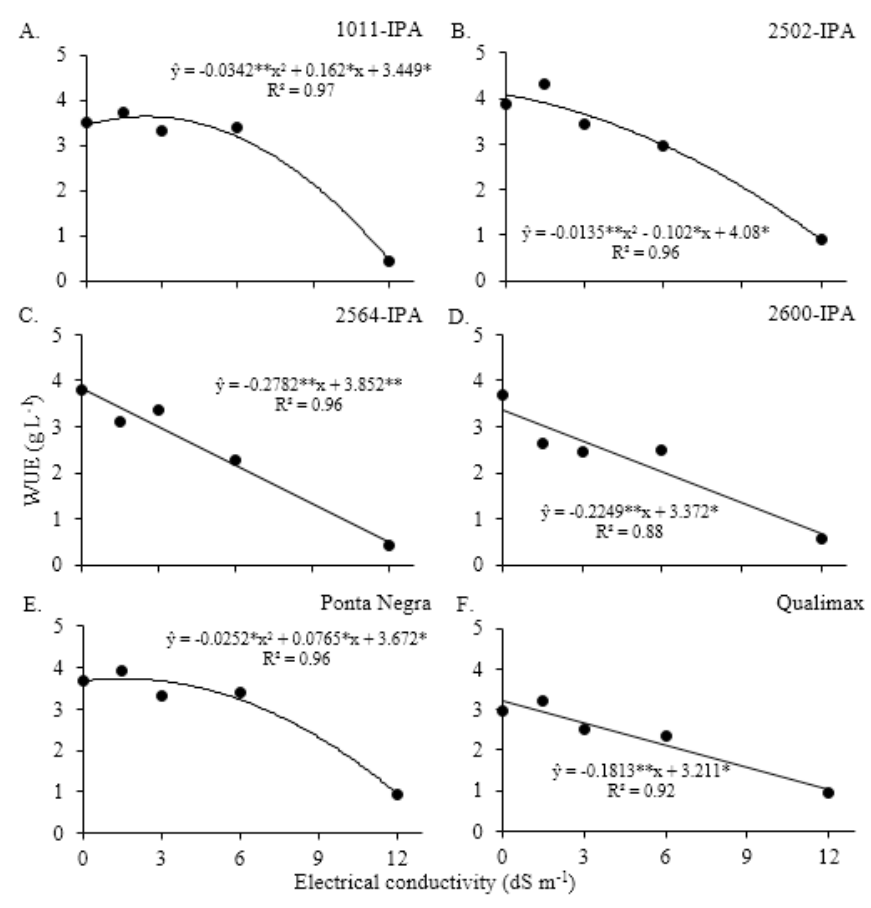

** and ${ }^{*}$ Significant regression coefficient at 0.01 and 0.05 probability, respectively

Figure 3. Water use efficiency (WUE) of sorghum varieties subjected to different salinity levels of the irrigation water

Plants under treatments with $\mathrm{EC}_{\mathrm{w}}$ of $12.0 \mathrm{dS} \mathrm{m}^{-1}$ had no grain yields (Figure 4 ). The evaluated varieties presented similar results, with more pronounced reductions when the $\mathrm{EC}_{\mathrm{w}}$ exceeded $3 \mathrm{dS} \mathrm{m}^{-1}$. The 1011-IPA, 2502-IPA, and Ponta Negra were less sensitive to salinity, with reductions of $50 \%$ in grain production with the $\mathrm{EC}_{\mathrm{w}}$ of $5.24,5.01$, and $5.08 \mathrm{dS} \mathrm{m}^{-1}$, respectively. The 2564-IPA, 2600-IPA, and Qualimax varieties were more sensitive to the salinity effects, with reductions of $50 \%$ of the production with $\mathrm{EC}_{\mathrm{w}}$ of $3.52,2.75$, and $4.38 \mathrm{dS} \mathrm{m}^{-1}$, respectively.

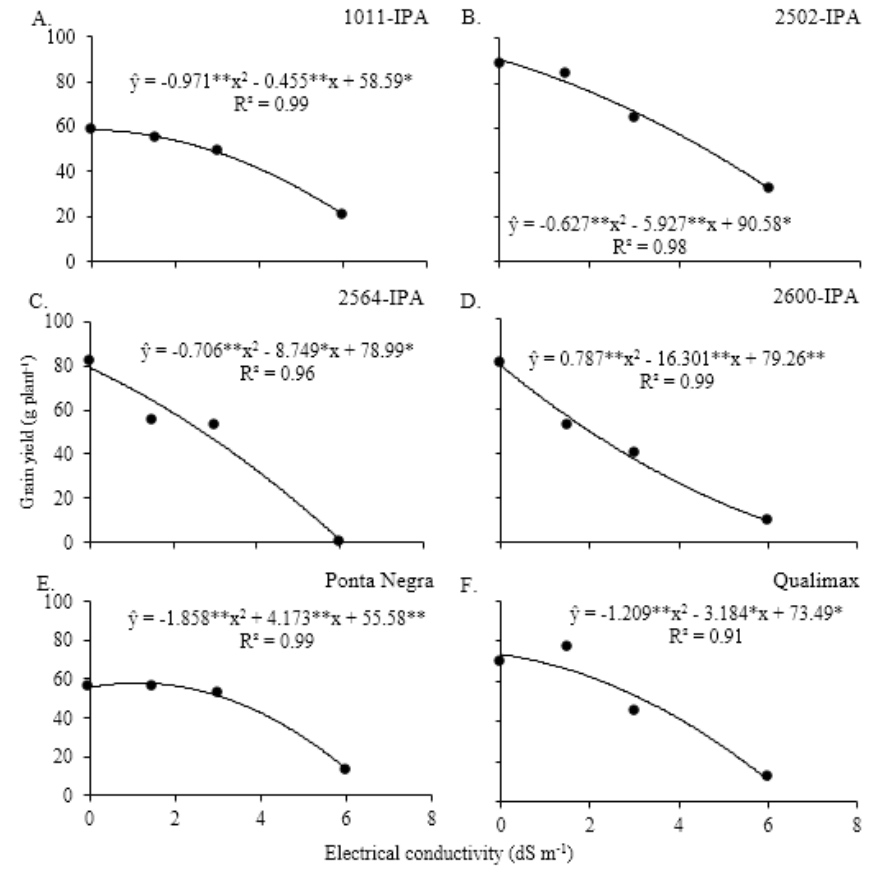

** and ${ }^{*}$ Significant regression coefficient at 0.01 and 0.05 probability, respectively

Figure 4. Grain yield of sorghum varieties subjected to different salinity levels of the irrigation water 
The reductions in grain yield found for the sorghum varieties is one of the main effects of salinity on plants; similar effects are found for other species of agronomic interest, such as peanut (Correia et al., 2009), melon (Medeiros et al., 2008), and cucumber (Medeiros et al., 2009). According to Rhoades et al. (2000), salinity affects the development and reproduction of plants. Salinity reduces seed development and cause symptoms similar to those of water stress. Soil salinity is usually caused by irrigation with salt water and by the combination of water, soil, and crop managements. It results in increased crop cycle, and reduced grain yield and quality, influencing directly the viability of the crop.

Similar reductions in grain yield are found in other studies with different grain species. Igartua et al. (1995) found reductions of up to $72 \%$ in grain yield of 31 sorghum genotypes when using a salinity level $\left(\mathrm{EC}_{\mathrm{w}}\right)$ of the irrigation water of $12 \mathrm{dS} \mathrm{m}^{-1}$. Hassanein et al. (2010) found reductions of up to $21 \%$ in sorghum grain yield when using a salinity level

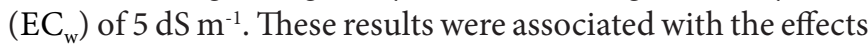
of salinity on different physiological processes, especially the translocation of water and solutes, cell division, and cell differentiation.

The sorghum varieties 2502-IPA and 1011-IPA presented

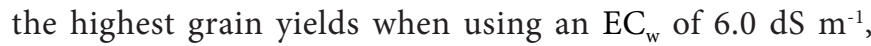
followed by Ponta Negra, Qualimax, and 2600-IPA. The 2564IPA variety was the most sensitive to the salinity effects, with no grain yield at the salinity level of $6.0 \mathrm{dS} \mathrm{m}^{-1}$ (Table 2). The 2502-IPA variety had higher grain yield than the others when using an $\mathrm{EC}_{\mathrm{w}}$ of $3.0 \mathrm{dS} \mathrm{m}^{-1}$, followed by 2564-IPA, Ponta Negra, and 1011-IPA.

Table 2. Grain yield (g plant ${ }^{-1}$ ) of sorghum varieties irrigated with water with different salinity levels

\begin{tabular}{|c|c|c|c|c|c|}
\hline \multirow{2}{*}{ Variety } & \multicolumn{5}{|c|}{$E C\left(d S m^{-1}\right)$} \\
\hline & 0 & 1.5 & 3.0 & 6.0 & $12.0^{\star *}$ \\
\hline 1011-IPA & $58.94 \mathrm{C}$ & $54.79 b$ & $49.18 b$ & $20.79 b$ & - \\
\hline 2502-IPA & $89.10 \mathrm{a}$ & $84.24 \mathrm{a}$ & $64.19 \mathrm{a}$ & $32.94 \mathrm{a}$ & - \\
\hline 2564-IPA & $82.24 \mathrm{a}$ & $55.63 \mathrm{~b}$ & $52.88 \mathrm{~b}$ & $0.00 \mathrm{~d}$ & - \\
\hline 2600-IPA & $80.59 a$ & $53.03 b$ & $40.10 \mathrm{C}$ & $9.34 \mathrm{C}$ & - \\
\hline Ponta Negra & $56.02 \mathrm{C}$ & $56.47 \mathrm{~b}$ & $52.26 \mathrm{~b}$ & $13.57 \mathrm{C}$ & - \\
\hline Qualimax & $69.34 \mathrm{~b}$ & $77.08 \mathrm{a}$ & $44.74 \mathrm{c}$ & $12.24 \mathrm{C}$ & - \\
\hline
\end{tabular}

Means followed by the same letter in the columns do not differ by the Scott Knott test at 0.05 probability level. ${ }^{* *}$ No production

The tested varieties were able to develop, with grain yield within their average for the crop when irrigated with salt water, except the 2564-IPA variety. This indicates that this variety has greater sensitivity to salinity compared to the other materials evaluated. The 1011-IPA, and 2502-IPA showed good results when subjected to the salinity levels, and can be alternative varieties for places that have availability of salt water with $\mathrm{EC}_{\mathrm{w}}$ of up to $6 \mathrm{dS} \mathrm{m}^{-1}$, and similar soil and climatic conditions, since above this salinity level, reductions of more than $50 \%$ in grain production may occur.

\section{Conclusions}

1. The sorghum varieties 2502-IPA and 1011-IPA presented

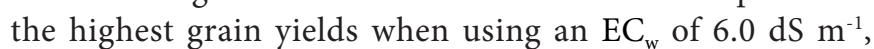
followed by Ponta Negra, Qualimax, and 2600-IPA.

2. The 2564-IPA, 2600-IPA, and Qualimax varieties were more sensitive to the salinity effects, with reductions of $50 \%$ of the production with $\mathrm{EC}_{\mathrm{w}}$ of $3.52,2.75$, and $4.38 \mathrm{dS} \mathrm{m} \mathrm{m}^{-1}$, respectively.

\section{Literature Cited}

Albuquerque, C. J. B.; Jardim, R. R.; Alves, D. D.; Guimarães, A. de S.; Porto, E. M. V. Características agronômicas e bromatológicas dos componentes vegetativos de genótipos de sorgo forrageiro em Minas Gerais. Revista Brasileira de Milho e Sorgo, v.12, p.164-182, 2013. https://doi.org/10.18512/1980-6477/rbms. v12n2p164-182

Aquino, A. J. S. de; Lacerda, C. F. de; Bezerra, M. A.; Gomes Filho, E.; Costa, R. N. T. Crescimento, partição de matéria seca e retenção de $\mathrm{Na}^{+}, \mathrm{K}^{+}$e Cl- em dois genótipos de sorgo irrigados com águas salinas. Revista Brasileira de Ciência do Solo, v.31, p.961-971, 2007. https://doi.org/10.1590/S0100-06832007000500013

Correia, K. G.; Fernandes, P. D.; Gheyi, H. R.; Nobre, R. G.; Santos, T. da S. Crescimento, produção e características de fluorescência da clorofila a em amendoim sob condições de salinidade. Revista Ciência Agronômica, v.40, p.514-521, 2009.

Guimarães, M. J. M.; Simões, W. L.; Tabosa, J. N.; Santos, J. E. dos; Willadino, L. Cultivation of forage sorghum varieties irrigated with saline effluent from fish-farming under semiarid conditions. Revista Brasileira de Engenharia Agrícola e Ambiental, v.20, p.461-465, 2016. https://doi.org/10.1590/1807-1929/agriambi. v20n5p461-465

Hassanein, M. S.; Ahmed, A. G.; Zaki, N. M. Growth and productivity of some sorghum cultivars under saline soil condition. Journal of Applied Sciences Research, v.6, p.1603-1611, 2010.

Igartua, E.; Gracia, M. P.; Lasa, J. M. Field responses of grain sorghum to a salinity gradient. Field Crops Research, v.42, p.15-25, 1995. https://doi.org/10.1016/0378-4290(95)00018-L

Medeiros, J. F. de; Dias, N. da S.; Barros, A. D. de. Manejo da irrigação e tolerância do meloeiro à salinidade da água de irrigação. Revista Brasileira de Ciências Agrárias, v.3, p.242-247, 2008. https://doi. org/10.5039/agraria.v3i3a264

Medeiros, P. R. F. de; Duarte, S. N.; Dias, C. T. S. Tolerância da cultura do pepino à salinidade em ambiente protegido. Revista Brasileira Engenharia Agrícola Ambiental, v.13, p.406-410, 2009. https:// doi.org/10.1590/S1415-43662009000400006

Mondo, V. H. V.; Carvalho, S. J. P. de; Labonia, V. D. de S.; Dourado Neto, D.; Cicero, S. M. Comparação de métodos para estimativa de área foliar em plantas de milho. Revista Brasileira de Milho e Sorgo, v.8, p.233-246, 2009. https://doi.org/10.18512/1980-6477/ rbms.v8n3p233-246

Niu, G.; Xu, W.; Rodrigues, D.; Sun, Y. Growth and physiological responses of maize and sorghum genotypes to salt stress. International Scholarly Research Notices, v.2012, p.1-12, 2012.

Reddy, S. J.; Amorim Neto, M. da S. Dados de precipitação, evapotranspiração potencial, radiação solar global de alguns locais e classificação climática do Nordeste do Brasil. Petrolina: Embrapa Semiárido, 1983. 280p.

Rhoades, J. D.; Kandiah, A.; Mashali, A. M. Uso de águas salinas para produção agrícola. Campina Grande: UFPB, 2000. 27p. Irrigação e Drenagem, 48 
Santos, F. C. de; Albuquerque Filho, M. R. de; Resende, Á. V. de; Oliveira, A. C. de; Gomes, T. C.; Oliveira, M. S. Adubações nitrogenada e potássica no sorgo biomassa -produtividade e qualidade de fibra. Revista Brasileira de Milho e Sorgo, v.13, p.113, 2014. https://doi.org/10.18512/1980-6477/rbms.v13n1p1-13

Santos Júnior, J. A.; Gheyi, H. R.; Guedes Filho, D. H.; Soares, F. A. L.; Dias, N. da S. Efficiency of water use in sunflower grown in hydroponic system under saline stress. Engenharia Agrícola, v.33, p.718-729, 2013. https://doi.org/10.1590/S010069162013000400011

Shakeri, E.; Emam, Y. Selectable traits in sorghum genotypes for tolerance to salinity stress. Journal of Agricultural Science and Technology, v.19, p.1319-1332, 2017.

Shakeri, E.; Emam, Y.; Tabatabaei, S. A.; Sepaskhah, A. R. Evaluation of grain sorghum (Sorghum bicolor L.) lines/cultivars under salinity stress using tolerance indices. International Journal of Plant Production, v.11, p.101-116, 2017.

Silva, A. G. da; Barros, A. S.; Silva, L. H. C. P. da; Moraes, E. B. de; Pires, R.; Teixeira, I. R. Avaliação de cultivares de sorgo granífero na safrinha no sudoeste do estado de Goiás. Pesquisa Agropecuária Tropical, v.39, p.168-174, 2009.

Steppuhn, H.; Raney, J. P. Emergence, height, and yield of canola and barley grown in saline root zones. Canadian Journal of Plant Science, v.85, p.815-827, 2005. https://doi.org/10.4141/P04-199
Sun, Y.; Niu, G.; Osuna-Avila, P.; Zhao, L.; Ganjegunte, G. K.; Peterson, G. C.; Peralta-Videa, J. R.; Gardea-Torresdey, J. L. Variability in salt tolerance of Sorghum bicolor L. Agricultural Science, v.2, p.9-21, 2014. https://doi.org/10.12735/as.v2i1p9

Tabatabaei, S. A.; Anagholi, A. Effects of salinity on some characteristics of forage sorghum genotypes at germination stage. International Journal of Agriculture and Crop Sciences, v.4, p.979-983, 2012.

Taiz, L.; Zeiger, E. Fisiologia vegetal. 5.ed. Porto Alegre: Artmed, 2013. 954p.

Tardin, F. D.; Almeida Filho, J. E. de; Oliveira, C. M. de; Leite, C. E. do P.; Menezes, C. B. de; Magalhães, P. C.; Rodrigues, J. A. S.; Schaffert, R. E. Avaliação agronômica de híbridos de sorgo granífero cultivados sob irrigação e estresse hídrico. Revista Brasileira de Milho e Sorgo, v.12, p.102-117, 2013. https://doi. org/10.18512/1980-6477/rbms.v12n2p102-117

Tigabu, E.; Andargie, M.; Tesfaye, K. Genotypic variation for salinity tolerance in sorghum [Sorghum bicolor (L.) Moench] genotypes at early growth stages. Journal of Stress Physiology \& Biochemistry, v.9, p.253-262, 2013.

Willadino, L.; Camara, T. R. Tolerância das plantas à salinidade: Aspectos fisiológicos e bioquímicos. Enciclopédia Biosfera, v.6, p.1-23, 2010. 